\title{
Assessing the Origins, Evolution and Prospects of National Innovation Systems
}

\author{
Pedro López-Rubio $^{1}$ (D) $\cdot$ Norat Roig-Tierno $^{2} \cdot$ Francisco Mas-Verdú $^{1}$
}

Received: 3 July 2020 / Accepted: 30 November 2020 / Published online: 6 January 2021

(C) The Author(s), under exclusive licence to Springer Science+Business Media, LLC part of Springer Nature 2021

\begin{abstract}
This paper assesses the origins, evolution and prospects of national innovation systems (NISs) using bibliometric techniques. All available data in the Web of Science Core Collection database up to and including the year 2017 are considered in the analysis. Both the number of NIS studies and the number of citations of these studies reflect the influence of this topic and the attention and growing interest of the scientific community, public administrations and international organisations in NIS research. The cocitation analysis of cited references provides a historical view of the origins of the NIS, and the bibliographic coupling between the documents gives a current overview of the status of NIS research. Our approach highlights the fact that many studies belong to previous, well-developed research streams. We also examine the topics covered by recent studies in each stream and the evolution of the most common keywords over time. In conclusion, we propose a research agenda based on three pillars: (1) the adaptation of innovation systems to the current global economic crisis and the application of the Quintuple Helix model to deal with this new scenario, (2) the adaptation of innovation systems to developing countries and (3) the specific fit of entrepreneurship and entrepreneurial innovations into NIS research.
\end{abstract}

Keywords National innovation systems - Quintuple Helix · Adaptation · Entrepreneurship · Bibliometrics

JEL Classification O30 O31 O38

Pedro López-Rubio

pedloru@doctor.upv.es

Norat Roig-Tierno

norat.roig@esic.edu

Francisco Mas-Verdú

fmas@upvnet.upv.es

Extended author information available on the last page of the article 


\section{Introduction}

The concept of the national innovation system (NIS; Freeman 1987; Lundvall 1992; Nelson 1993) originated between the end of the 1980s and the middle of the 1990s, when it became a popular topic in debates on European industrial policy. Bengt-Åke Lundvall was the first scholar to use this term, noting that the idea was actually proposed by Friedrich List in his book The National System of Political Economy (List 1841). The collaboration between Chris Freeman, Richard Nelson and Bengt-Åke Lundvall in the International Federation of Institutes for Advanced Study (IFIAS) was crucial for the subsequent development of the concept. Three books pioneered the idea of the NIS: Technology Policy and Economic Performance: Lessons from Japan, by Freeman (1987), National Systems of Innovation: Towards a Theory of Innovation and Interactive Learning, edited by Lundvall (1992) and National Innovation System: A Comparative Analysis, edited by Nelson (1993).

According to these pioneers, the NIS can be defined as 'the network of institutions in the public and private sectors whose activities and interactions initiate, import, modify and diffuse new technologies' (Freeman 1987, p. 1), 'the organizations and institutions involved in search and exploring such as $\mathrm{R} \& \mathrm{D}$ departments, technological institutes and universities, but also all parts and aspects of the economic structure and the institutional setup affecting learning as well as searching and exploring' (Lundvall 1992 , p. 12) or 'the set of institutions whose interactions determine the innovative performance of national firms' (Nelson 1993, p. 4). These definitions imply that the NIS has two main objectives: (1) to show international differences or similarities in the ability of countries to innovate and be at the technological frontier and (2) to offer policy suggestions to support firms' innovative activities (Vertova 2014).

Since the concept was coined, an international body of literature has documented the growing influence of the NIS approach. Several supranational organisations, most notably not only the Organisation for Economic Cooperation and Development (OECD) but also the European Union (EU) through the European Commission, as well as the World Bank, have embraced the concept of the NIS as an integral part of their analytical perspective. The innovation systems approach is also widespread in Scandinavia and Western Europe in academic and policymaking contexts (Lundvall et al. 2002).

Academic studies of NISs initially aimed at understanding differences in technological development and the profiles of technological specialisation between countries. However, since the beginning of the 2000 s, academic studies have increasingly focused on the relationship between the output of the innovation system and the factors that influence this system (e.g. Edquist 2004; Lundvall 2007; Bergek et al. 2008). Innovation, diffusion and use of technology, also known as technological dynamics, are the outputs of innovation systems, resulting from influences from abroad, activities within the business sector and interaction with other actors within society. A wide range of processes influence a country's technological dynamics. These processes include knowledge, skills, demand, finance and institutions, and they are affected by numerous policies and actors (Fagerberg 2017). Consequently, NISs may differ greatly from one country to another, and a policy mix that works in one context may not suit another (Flanagan et al. 2011; Borras and Edquist 2013). 
In view of the extent of the literature, the main goal of this study is to structure a conceptual framework for this research field, identifying how the concept has been established in the literature and how it has evolved. This paper describes the foundations and evolution of the NIS literature, giving scholars a stronger and more holistic view of the systemic approach to innovation.

We focus on a single research question:

RQ1. Based on the origins of the NIS, how has this research field evolved and what are its prospects?

To answer this question, we use a literature review approach. This approach is based on robust empirical bibliometric analysis followed by qualitative analysis of core documents. Using the key bibliometric methods of performance indicators, science mapping of bibliographic coupling, co-citations and keyword co-occurrence, we identify the most productive and influential authors, institutions and countries, as well as the historical development of the literature and the main streams within it. Bibliometric analysis is also used as a basis for qualitative analysis of the core literature, which in turn is used to build the narrative for this study.

This paper is structured as follows. The 'Methods' section describes the method. The 'Results' section presents the results. Finally, the 'Conclusions' section summarises the key conclusions.

\section{Method}

In this study, bibliometric techniques were used to develop a comprehensive overview of NIS research. The data source was the Web of Science Core Collection (WoS CC) database, which belongs to Clarivate Analytics. The WoS CC database is a digital scientific database that is internationally recognised by researchers for its high quality. It has become one of the main tools for searching for and evaluating different types of publications and journals. It contains more than 15,000 journals and 50,000,000 classified documents sorted into 251 categories and 150 thematic research areas (López-Rubio et al. 2018).

The search performed in the WoS CC was Topic = 'national innovation system' OR 'national innovation systems' OR ‘national innovations system' OR 'national innovations systems' OR 'national system of innovation' OR 'national systems of innovation' OR 'national system of innovations' OR 'national systems of innovations'. This search was conducted in December 2018 and covered all years up to and including 2017. The search returned 1107 documents. This set of documents comprised 580 'articles', 334 'proceedings papers', 69 'articles; book chapters', 58 'articles; proceedings papers', 26 'book reviews', 24 'reviews', seven 'editorial materials', four 'books', two 'news items', one 'book chapter', one 'letter' and one 'meeting abstract'. The WoS allows one document to be classified as several types.

These 1107 documents span 57 research areas. Only 18 of these areas are associated with more than 10 studies. As with document types, one study can cover multiple research areas. Figure 1 shows these 18 major research areas. Business economics is the primary research area, with substantially more documents than any other. This area is 


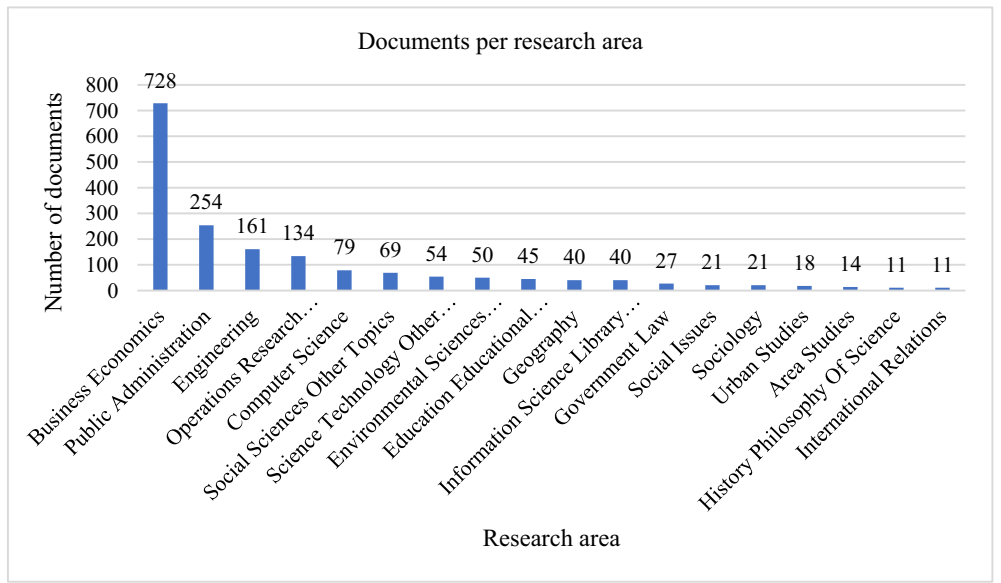

Fig. 1 Research areas with more than 10 NIS studies indexed in the WoS CC

followed by public administration (254). These results show that NIS studies generally have a dual perspective that spans business administration and management as well as public governance.

The documents corresponding to these results were analysed using two key bibliometric procedures: performance analysis and science mapping (Cobo et al. 2011). Bibliometric performance analysis uses a wide range of indicators and techniques. These indicators include the number of published studies and the number of citations (where publications are counted by country, university or author), the h-index, and the word frequency analysis. The h-index is a popular indicator amongst researchers. The calculation of the h-index involves the number of publications and citations. A variable (author, journal, country, institution, etc.) has an h-index of $\mathrm{N}$ when $\mathrm{N}$ documents have been cited at least $\mathrm{N}$ times (Hirsch 2005). However, the hindex has limitations. For example, this indicator does not benefit researchers who have extremely cited documents and moderate productivity since they would have a similar or equal h-index as researchers with moderate or highly cited papers. In this study, a range of bibliometric indicators were calculated because certain limitations can be overcome by evaluating the research field using more than one indicator (Martin 1996; Egghe 2006).

Science mapping is another key procedure in bibliometrics. Science mapping consists of graphical representations of how research fields, topics and individual papers are interrelated. A bibliometric map represents a scientific field by determining its cognitive structure, evolution and main actors (Small 1999). The most commonly used bibliometric maps include bibliographic coupling (Kessler 1963), co-citation analysis (Small 1973) and keyword co-occurrence in documents (Callon et al. 1983).

Bibliographic coupling measures the shared intellectual background of documents based on the references shared among documents (Kessler 1963). This approach suggests that the more shared references there are, the stronger the theoretical foundations shared by the two documents will be. According to Glänzel and Czerwon (1996), bibliographic coupling highlights hot topics. Over a long analysis period, it underscores topical citing papers. Bibliographic coupling links documents with a similar research focus (Jarvening 2007), revealing the knowledge structure of a field. By calculating the 
bibliographic coupling strength for all the documents in our data set, we were able to cluster and visualise networks of shared knowledge. These calculations were performed using the document as the unit of analysis and a full counting method.

Co-citation analysis identifies the shared background of the publications in a data set. Two documents are co-cited if one or more documents cite both articles (Small 1973). The weight of co-citation is based on the count of articles that co-cite the two documents. Co-citation analysis was performed using the full counting method and the references as the unit of analysis. Thus, co-citation analysis creates a network of cited documents rather than linking the documents in the data set (Garfield 2001).

Using bibliographic coupling and co-citation analysis in parallel allowed us to observe the structure of both the theoretical background and the current challenges of research in this area. In this study, co-citation analysis offers a historical view of the origins of this field, whilst bibliographic coupling gives a current overview of knowledge in this area (Youtie et al. 2013; Suominen et al. 2019).

Finally, keyword co-occurrence was used to study the conceptual structure of this research field based on the keywords of documents and their evolution over time (Callon et al. 1983).

VOSviewer software (Van Eck and Waltman 2010) was used to perform the science mapping analysis and to analyse each network cluster. Other science mapping software tools are also capable of performing this analysis (Cobo et al. 2011). Core documents were identified not only by calculating the number of connections but also by evaluating how valuable the connections are. For each main stream in the NIS literature, five documents were selected for evaluation. These documents were selected based on their citation scores, selecting the highest in each cluster.

The clusters under analysis were then labelled. Each of the authors individually read the five most cited documents in each cluster. The authors then independently determined the main research streams. Finally, they worked towards a consensus until agreement was reached on the label for each cluster. In the labelling process, the researchers considered all the documents in a cluster and used the network measures to evaluate the weighting of each individual document.

\section{Results}

\section{Publications and Citations in NIS Research}

The search was conducted in December 2018. It returned 1107 documents indexed in the WoS CC between 1990 and 2017. Up to 2017, these 1107 documents had received 16,268 citations, equating to 16.2 citations per study. The h-index was 64 .

Figure 2 shows the publications and citations per year. The first NIS research study indexed in the WoS CC was published in 1990. One study was also published each year in 1991 and 1992. The first study, 'Management of national technology programs in a newly industrialised country - Taiwan' (Chiang 1990), addresses the eight national technology programmes launched in Taiwan in the early 1980s and the differences between Taiwan's experience in these programmes and those of the most industrialised countries. The second document, the book How do National Systems of Innovation differ? A critical analysis of Porter, Freeman, Lundvall and Nelson (McKelvey 1991), 


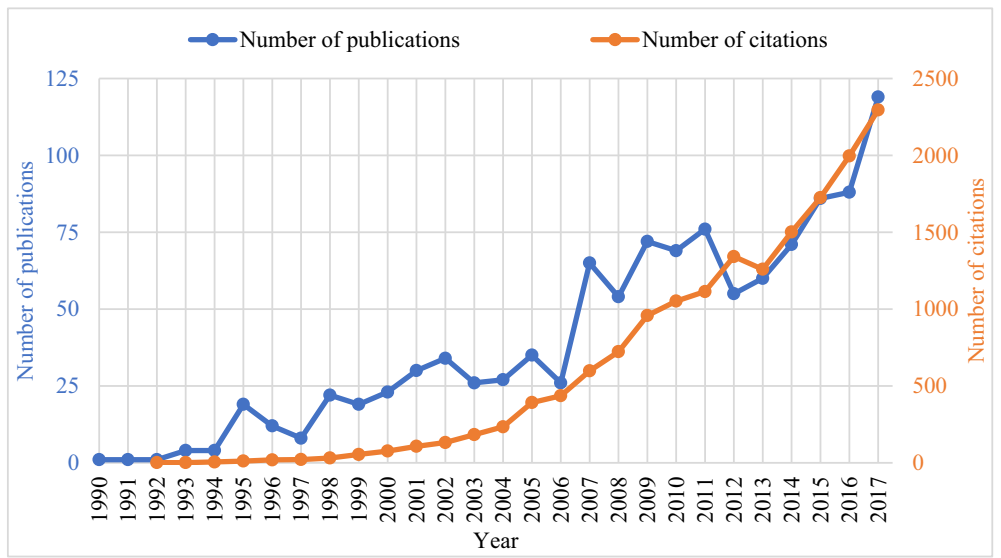

Fig. 2 Number of publications and citations of NIS research by year

analyses the approaches of the pioneers of NIS. The third document, the article 'The U.S. National Innovation System: Origins and prospect for change' (Mowery 1992), analyses the early U.S. NIS and explores how it should evolve given the international economic and technological environment emerging at the time.

From 1993 to 2006, the annual number of publications ranged from 4 to 35 . This number oscillated, exceeding the 50-study threshold in 2007. Since 2012, there has been a continuous upward trend of annual publications, starting with 55 studies in 2012. The 100-study threshold was surpassed in 2017, when the maximum (119 studies) was achieved. A substantial increase in NIS studies took place in 2007, although the annual upward trend did not begin until 2012. According to Fig. 2, the evolution of citations reflects a consistent year-on-year increase, except from 2012 to 2013, when the number of citations decreased from 1342 to 1259 . The 500- and 1000citation thresholds were surpassed in 2007 and 2010, respectively. The maximum number of citations (2296) occurred in 2017.

Overall, both the number of NIS studies and the number of citations of these studies reflect their influence and the attention and growing interest of the scientific community in NIS research. This interest has been especially pronounced since 2007, when the 50study and 500-citation thresholds were broken.

\section{The Most Productive and Influential Authors in NIS Research}

Since its emergence, NIS research has been characterised by increasing participation by researchers. One critical issue in developing an overview of NIS research is to determine the most productive and influential authors in this field. Some well-known authors may not appear because of the nature of this classification. Their absence may be a consequence of the year in which certain journals were indexed in the WoS CC or the fact that certain popular books are not indexed in the WoS. The classification in Table 1 shows the 17 authors with at least three studies and 100 citations. The classification is sorted by total citations. Where more than one author has the same number of citations, the order is based on the number of studies. The h-index is a 
Table 1 The most productive and influential authors in NIS research

\begin{tabular}{|c|c|c|c|c|c|c|c|}
\hline $\mathrm{R}$ & Author & Affiliation & Country & TS & $\mathrm{TC}$ & $\mathrm{h}$ & $\mathrm{C} / \mathrm{S}$ \\
\hline 1 & Freeman C & Univ Sussex & UK & 3 & 1086 & 3 & 362.0 \\
\hline 2 & Lundvall BA & Aalborg Univ & Denmark & 8 & 705 & 5 & 88.1 \\
\hline 3 & Mowery DC & UC Berkeley & USA & 6 & 426 & 5 & 71.0 \\
\hline 4 & Archibugi D & CNR & Italy & 7 & 404 & 5 & 57.7 \\
\hline 5 & Autio E & Imperial College London & UK & 6 & 354 & 5 & 59.0 \\
\hline 6 & Liu XL & Chinese Acad Sci & China & 4 & 294 & 3 & 73.5 \\
\hline 7 & Kenney M & UC Berkeley & USA & 4 & 277 & 4 & 69.3 \\
\hline 8 & Niosi J & Univ Quebec Montreal & Canada & 7 & 245 & 4 & 35.0 \\
\hline 9 & Michie J & Univ Oxford & UK & 4 & 233 & 3 & 58.3 \\
\hline 10 & Fagerberg J & Univ Oslo & Norway & 4 & 222 & 4 & 55.5 \\
\hline 11 & Motohashi K & Univ Tokyo & Japan & 4 & 186 & 3 & 46.5 \\
\hline 12 & Dodgson M & Univ Queensland & Australia & 3 & 175 & 3 & 58.3 \\
\hline 13 & Kaiser R & Univ Siegen & Germany & 3 & 122 & 2 & 40.7 \\
\hline 14 & Vanhaverbeke W & Hasselt Univ & Belgium & 3 & 121 & 3 & 40.3 \\
\hline 15 & Intarakumnerd P & Grad Inst Policy Studies GRIPS & Japan & 3 & 116 & 2 & 38.7 \\
\hline 16 & Chen KH & Chinese Acad Sci & China & 3 & 101 & 2 & 33.7 \\
\hline 17 & Guan JC & Chinese Acad Sci & China & 3 & 101 & 2 & 33.7 \\
\hline
\end{tabular}

$R$ ranking, $T S$ total studies, $T C$ total citations, h h-index, $\mathrm{C} / \mathrm{S}$ citations per study

composite indicator that combines productivity and influence. In contrast, citations per study are simply the ratio of the total number of studies to the total number of citations.

Lundvall has the most NIS studies indexed in the WoS CC. Lundvall also has the best combination of productivity and influence, with an h-index of 5. This h-index is shared by Mowery, Archibugi and Autio. The lists of scholars with the most citations and citations per study are both headed by Freeman. Although Freeman has only three NIS studies indexed in the WoS CC, this scholar has many more citations than the other authors in the list. The author with the second highest number of citations is Lundvall, with 705 citations, followed by Mowery, Archibugi and Autio.

To strengthen the analysis, science mapping of the author co-citations was conducted. Author co-citation analysis reveals authorship structures and connections between the authors who are cited together (co-cited) most frequently (White and Griffith 1981). Figure 3 presents the results of this analysis. A threshold of 55 citations was used, and the 100 most representative links were considered. Figure 3 confirms the importance of Lundvall (849 citations with a total link strength of 10,131) and Freeman (727 citations with a total link strength of 9414) in NIS research. The size of the circles associated with these authors and their centrality in Fig. 3 are notable. However, this map also shows other eminent authors such as Nelson (affiliated with Columbia University in the USA; 760 citations with a total link strength of 9814), the OECD (728 citations with a total link strength of 7161) and, to a lesser extent, Edquist (affiliated with Lund University in Sweden; 326 citations with a total link strength of 4484). In addition to the OECD, two further international organisations (the European Commission and the World Bank) appear in the co-citation map of authors. 


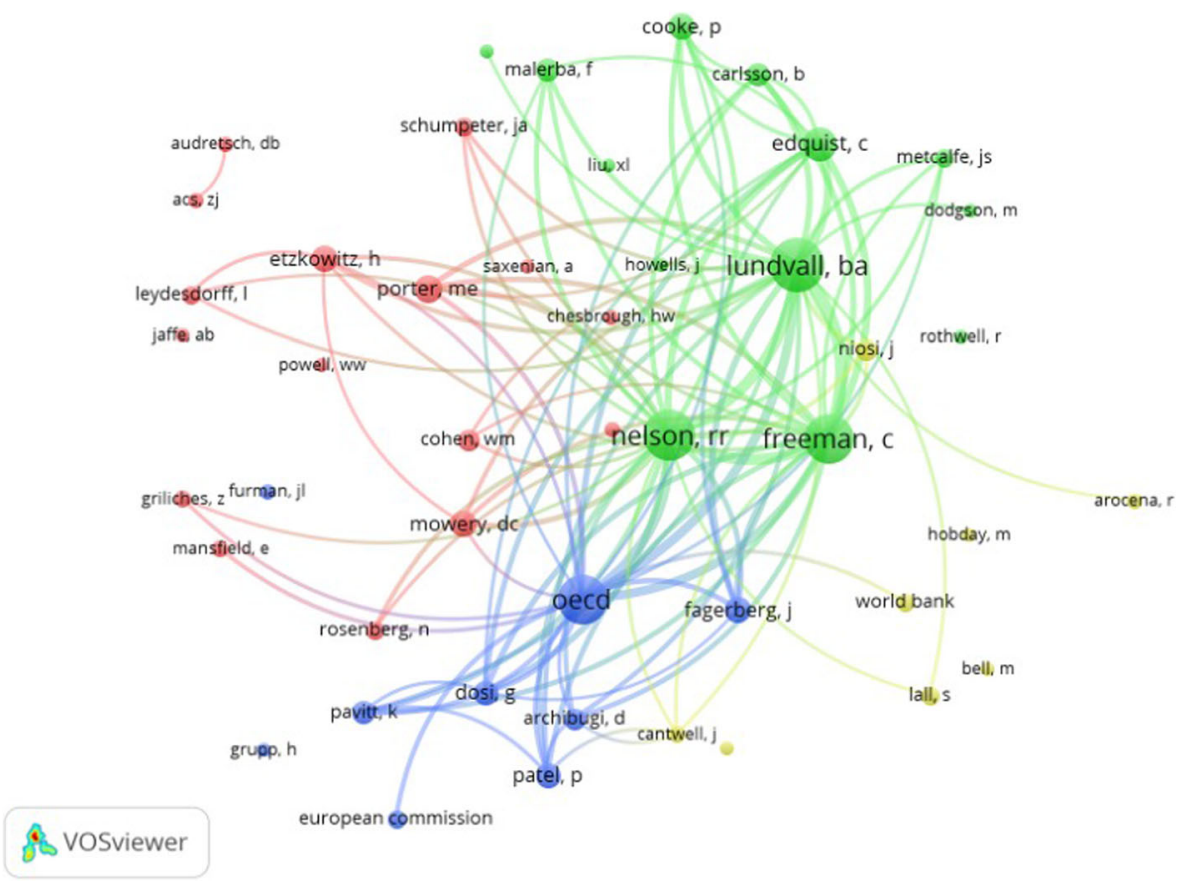

Fig. 3 Co-citation map of authors

The results from Table 1 and Fig. 3 show that the most influential authors work in institutions in Europe or the USA. Moreover, international organisations, especially the OECD, are prominent exponents of NIS research. These findings reveal that the NIS research field has gained considerable attention and exerts a growing influence amongst international organisations, the scientific community and public administrations in developed countries with a strong focus on innovation policies and activities.

\section{The Most Productive and Influential Institutions and Countries in NIS Research}

Table 2 lists the most productive and influential institutions according to the total number of studies by affiliated authors. The list shows the 18 institutions with at least seven NIS studies and 100 citations. Most are in Europe (13) and Asia (4).

According to Table 2, the University of Sussex (where Freeman is affiliated) has the most studies (18), the most citations (1420) and the best balance between productivity and influence (h-index $=11$ ). Aalborg University (where Lundvall is affiliated) has the second most studies (16) and citations (916) and the third highest h-index (7). The University of California Berkeley, Erasmus University of Rotterdam, Seoul National University and Utrecht University also have an h-index of 7. The University of Manchester has the second-best combination of productivity and influence (h-index = 9) and is the third most productive university with 14 studies.

As mentioned earlier, the University of Sussex has the most citations (1420), followed by Aalborg University (916), Fraunhofer Gesellschaft (916), the University of Cambridge (884) and the University of California Berkeley (638). Interestingly, some of these institutions are also highly ranked in terms of citations per study. The University of 
Table 2 The most productive and influential institutions in NIS research

\begin{tabular}{|c|c|c|c|c|c|c|c|c|}
\hline $\mathrm{R}$ & Institution & Country & $\mathrm{TS}$ & $\mathrm{TC}$ & $\mathrm{h}$ & $\mathrm{C} / \mathrm{S}$ & ARWU & QS \\
\hline 1 & Univ Sussex & UK & 18 & 1420 & 11 & 78.9 & $201-300$ & $301-500$ \\
\hline 2 & Aalborg Univ & Denmark & 16 & 916 & 7 & 57.3 & $201-300$ & $301-500$ \\
\hline 3 & Univ Manchester & UK & 14 & 520 & 9 & 37.1 & 34 & 35 \\
\hline 4 & Chinese Acad Sci & China & 12 & 117 & 4 & 9.8 & - & - \\
\hline 5 & Lund Univ & Sweden & 12 & 102 & 5 & 8.5 & $101-150$ & $141-150$ \\
\hline 6 & Fraunhofer Gesellschaft & Germany & 10 & 916 & 5 & 91.6 & - & - \\
\hline 7 & Univ Oslo & Norway & 10 & 283 & 6 & 28.3 & 62 & $201-250$ \\
\hline 8 & Seoul Natl Univ & South Korea & 10 & 219 & 7 & 21.9 & $101-150$ & 23 \\
\hline 9 & Aalto Univ & Finland & 9 & 240 & 5 & 26.7 & $301-400$ & $201-250$ \\
\hline 10 & CNRS & France & 9 & 174 & 5 & 19.3 & - & - \\
\hline 11 & UC Berkeley & USA & 8 & 638 & 7 & 79.8 & 5 & 8 \\
\hline 12 & $\mathrm{CNR}$ & Italy & 8 & 467 & 6 & 58.4 & - & - \\
\hline 13 & Erasmus Univ Rotterdam & Netherlands & 8 & 248 & 7 & 31.0 & 79 & $141-150$ \\
\hline 14 & Univ Tokyo & Japan & 8 & 210 & 4 & 26.3 & 22 & 19 \\
\hline 15 & Utrecht Univ & Netherlands & 8 & 198 & 7 & 24.8 & 51 & $201-250$ \\
\hline 16 & Univ Cambridge & UK & 7 & 884 & 5 & 126.3 & 3 & 7 \\
\hline 17 & PSL Res Univ Paris Comue & France & 7 & 160 & 4 & 22.9 & - & - \\
\hline 18 & Univ Chinese Acad Sci CAS & China & 7 & 101 & 3 & 14.4 & - & - \\
\hline
\end{tabular}

$R$ ranking, $T S$ total studies, $T C$ total citations, $h$ h-index, $C / S$ citations per study, $A R W U$ Academic Ranking of World Universities 2018, QS Quacquarelli Symonds University Ranking 2019

Cambridge has an average of 126.3 citations, followed by Fraunhofer Gesellschaft (91.6), the University of California Berkeley (79.8) and the University of Sussex (78.5).

Regarding the country analysis and based on the premise that research and innovation foster economic development and growth, public administrations increasingly focus on innovation policy and the NIS (OECD 2011, 2015; European Commission 2014). To develop a complete picture of NIS research, this section analyses the geographical origin of NIS publications. Some researchers change their affiliations over their working life and may have several affiliations at the same time. Therefore, a single author may have publications corresponding to two or more countries. In this analysis, country affiliation refers to the country where the author was working at the time the relevant document was published.

Table 3 presents the 23 countries with at least 15 NIS studies. This table includes the total number of NIS studies, total number of citations received by these studies, hindex, citations per study, 2018 Global Innovation Index (GII), 2018 Global Competitiveness Index (GCI), population in millions, gross domestic product (GDP) in billions of US dollars and GDP per capita in US dollars. The GII is an innovation performance index co-published by Cornell University, INSEAD Business School and the World Intellectual Property Organization (WIPO). It is calculated for 126 countries and is composed of 80 indicators. More detailed information can be found at https://www. globalinnovationindex.org. The GCI is a competitiveness index published by the World Economic Forum. It covers 140 countries and 98 indicators. This index can be consulted at https://www.weforum.org. Data on population, GDP and GDP per capita 


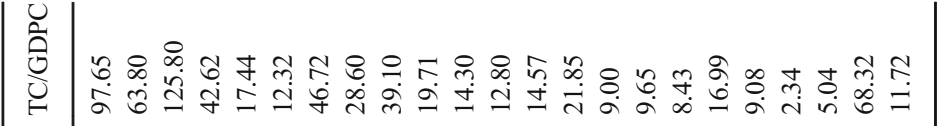

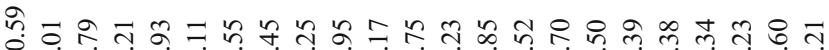
N

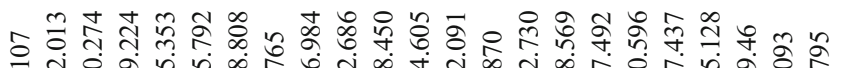

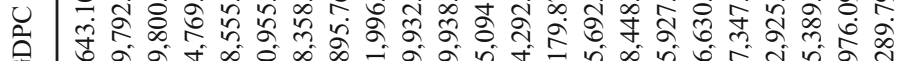

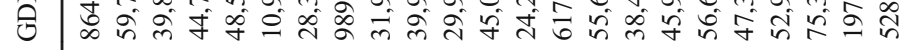

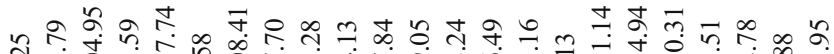

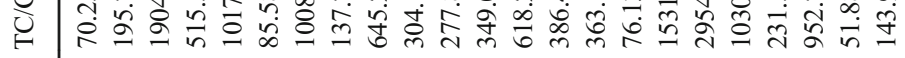

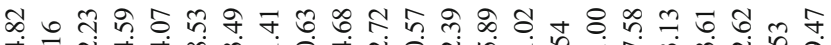

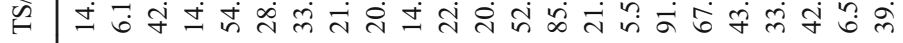

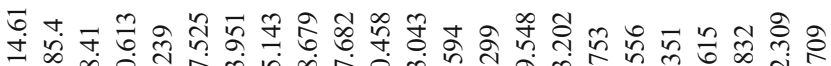

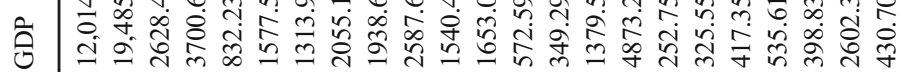
仓े

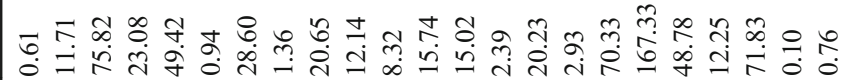
$\stackrel{0}{\frac{0}{n}}$

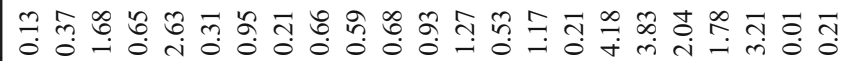
\& 0 \%

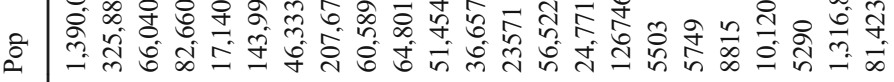

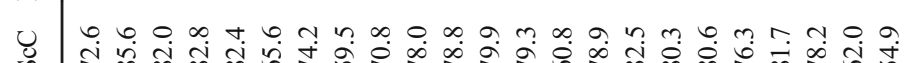
U

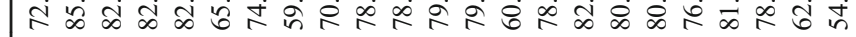

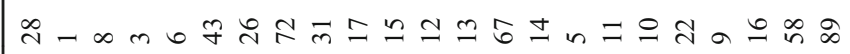

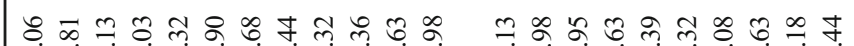

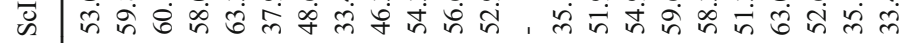

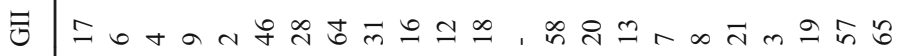

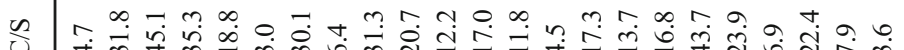
न 工

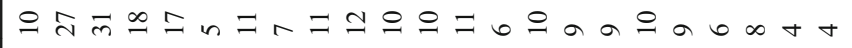

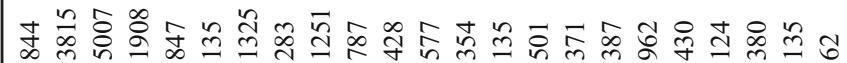
$\stackrel{\infty}{=}$ בิ

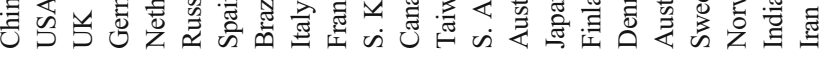
ฯ $\infty$ n-mn

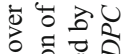
읍흉 원 记 离

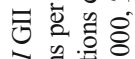
ธั

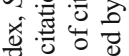
जि 荶运㤩 วิํㅠ 贾过苋 잉ㅎㅀ

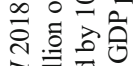
정 司氙 宅言哥 क्ष

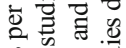

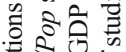

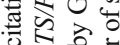
v 0 च 0 要自

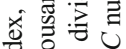
: ․․웡 की क्षै

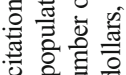
퓨은.

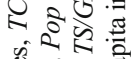

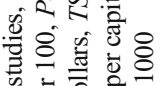

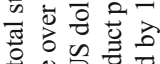
总造出

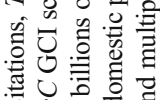
荧

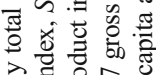

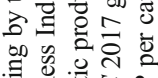
言. 范合 늉혀

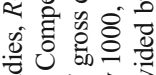
总范完:

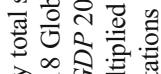

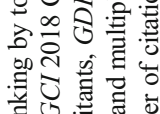

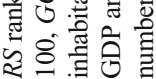


were collected for the year 2017. These data were gathered from the International Monetary Fund website (https://www.imf.org). This information was included in the study to show the bibliometric indicators in relation to innovation performance, competitiveness, population and national wealth.

According to the data from the WoS CC, China, the USA and the UK have the most publications, with more than 100 each. Germany, the fourth-placed country, lags some way behind. Regarding indicators of influence, the UK has the most citations (5007), the highest h-index (31) and the most citations per study (45.1). The USA has the second most citations (3815), the second highest h-index (27) and the fourth most citations per study (31.8). Germany has the third most citations (1908), the third highest h-index (18) and the third most citations per study (35.3). Other countries that perform well in any or several indicators of influence are Spain and Italy (more than 1000 citations each, an h-index of 11 and more than 30 citations per study), the Netherlands (an h-index of 17 and 847 citations) and Denmark (43.7 citations per study and 962 citations).

Based on the previous bibliometric indicators, the UK may be considered the leading country in NIS research, followed by the USA and, lagging some distance behind, Germany, Spain, Italy, Denmark, the Netherlands and China. Most countries in this ranking are European (12 countries; $52 \%$ of the list). These results are consistent with the origins of the NIS in the European industrial economies of the end of the 1980s, which transformed into knowledge-based economies. The term knowledge-based economy was coined to describe the shift of advanced economies towards greater dependence on knowledge, information and advanced skills, coupled with an increasing need for the business and public sectors to have ready access to these resources (OECD 1996).

Surprisingly, all BRICS countries (Brazil, Russia, India, China and South Africa) are also included in this ranking. The inclusion of these countries is linked to the challenge of adapting the innovation systems approach to developing countries (Lundvall et al. 2011; Lundvall 2016).

Certain Nordic and Central European countries such as Finland, Denmark, Norway, the Netherlands, Austria and Sweden are the most productive countries per million people. Denmark is noteworthy because it has a high number of citations per million people (177.33). This number is much higher than the second best, which is the UK with 75.82. Regarding productivity by GDP, the top five countries are Finland, South Africa, Denmark, the Netherlands and Taiwan. The total number of citations by GDP is led by Denmark, the UK, Finland, Austria and the Netherlands. China is by far the most productive country by GDP per capita, followed by India and, lagging some distance behind, South Africa, Brazil and Russia. This ranking reflects the fact that these countries are highly populated yet have a low GDP per capita. Lastly, the most cited countries by GDP per capita are the UK, China, India, the USA and Spain. These results show that developed countries with a strong focus on innovation policies and processes are leaders in NIS research. However, developing countries are also responsible for research in this field to diversify their economies and foster growth.

\section{The Most Cited and Influential Studies in NIS Research}

Many influential NIS papers have been published. One method to identify these influential studies is to classify publications by number of citations, which reflects their influence and popularity and the attention received from the scientific community (López-Rubio et al. 
2020). Table 4 presents the 30 most cited NIS studies according to the WoS CC. The total number of citations favours older papers because they have had more time to receive more citations. Therefore, the number of citations per year is also shown in Table 4.

According to Table 4, the five most cited papers have more than 450 citations and are focused on traditional NIS topics such as NIS history (Freeman 1995), institutional and organisational dimensions (Cooke et al. 1997), the national innovative capacity (Furman et al. 2002), the relationship between networking and innovation (Pittaway et al. 2004) and the national systems of production, innovation and competence building (Lundvall et al. 2002). These five studies are also amongst the top seven when ranked by citations per year. Surprisingly, however, the fifth- and sixth-ranked documents in this ranking are two papers published as recently as 2014 . These papers deal with the novel concept of the National System of Entrepreneurship (Acs et al. 2014) and with entrepreneurial innovation (Autio et al. 2014). These results highlight one pathway regarding the evolution and prospects of NIS research, which is broadening its focus to cover emerging actors such as entrepreneurs, who offer potential sources of innovation and interact with innovation systems.

\section{A Historical View of the Origins of the NIS}

The co-citation analysis of references provides a historical view of the origins of the NIS. A total of 31,283 cited references were identified. This number is too large to be practical for analysis. Therefore, Fig. 4 presents the co-citation map of the 67 cited references with at least 20 citations and the 100 most representative links. Table 5 groups these results by the four clusters determined by VOSviewer. A review of the five most cited studies in each cluster and analysis of the rest of the studies in the cluster revealed four research streams in the NIS literature: the systemic approach to innovation, institutional and organisational dimensions, the economics of innovation, the national capabilities regarding university-industry-government relations (the Triple Helix model; Etzkowitz and Leydesdorff 2000), innovative capacity, patents, R\&D productivity, technological learning, the openness of the economy and other such areas.

The co-citation map of references shows that cluster 1 (red) and cluster 2 (blue) are the core streams. Cluster 3 (green) and cluster 4 (yellow) are peripheral. Examination of these streams reveals that regardless of the focus (systemic approach to innovation and evolutionary economics, institutional and organisational dimensions, economics of innovation, or national capabilities), in all streams, the specific features of each country must be considered. These specific features depend on political, economic and sociocultural factors, as well as the legal, technological and environmental contexts. Accordingly, the Triple Helix model has evolved into the Quadruple Helix model, which 'encourages the perspective of the knowledge society, and of knowledge democracy for knowledge production and innovation', or the Quintuple Helix model, which 'stresses the necessary socioecological transition of society and economy' to address, for example, global warming (Carayannis et al. 2012, p. 1).

\section{A Contemporary Overview of NIS Research}

We performed bibliographic coupling analysis of the 66 documents with at least 60 citations (from the total pool of 1107 documents). The aim was to develop a 
Table 4 The 30 most cited NIS studies indexed in the WoS CC

\begin{tabular}{lll}
\hline $\mathrm{R}$ & $\mathrm{TC}$ & Author \\
\hline 1 & 820 & Freeman, C \\
& & \\
2 & 787 & Cooke, P; Uranga, MG; \\
& & Etxebarria, G \\
3 & 683 & $\begin{array}{l}\text { Furman, JL; Porter, ME; } \\
\text { Stern, S }\end{array}$ \\
4 & 519 & $\begin{array}{l}\text { Pittaway, L; Robertson, M; } \\
\text { Munir, K; Denyer, D; } \\
\end{array}$ \\
& & Neely, A
\end{tabular}

5470 Lundvall, BA; Johnson, B; Andersen, ES; Dalum, B

6383 Meyer-Krahmer, F; Meyer-Krahmer, $\mathrm{F}$

7354 Muller, E; Zenker, A

8282 Liu, XL; White, S

9240 Phene, A;

Fladmoe-Lindquist, K; Marsh, L

10239 Colombo, MG; Delmastro, M

11230 Owen-Smith, J; Riccaboni, M; Pammolli, F; Powell, WW

12221 Carlsson, B

13215 Mowery, DC; Oxley, JE

14210 Freeman, C

15206 Cooke, P; Uranga, MG; Etxebarria, G

16198 Hassink, R

17185 Fagerberg, J; Srholec, M

18173 Spencer, JW

19165 Le Bas, C; Sierra, C

20159 Metcalfe, JS

21158 Archibugi, D; Michie, J
Document title

PY C/Y

The National System of Innovation in historical

$1995 \quad 35.7$ perspective

Regional innovation systems: Institutional and

$1997 \quad 37.5$ organisational dimensions

The determinants of national innovative capacity

$2002 \quad 42.7$

Networking and innovation: a systematic review of the evidence

$2004 \quad 37.1$

National systems of production, innovation and competence building

Science-based technologies: university-industry inter- $1998 \quad 19.2$ actions in four fields

Business services as actors of knowledge

$2001 \quad 20.8$ transformation: the role of KIBS in regional and national innovation systems

Comparing innovation systems: a framework and application to China's transitional context

Breakthrough innovations in the US biotechnology industry: The effects of technological space and geographic origin

$2002 \quad 29.4$

ow effective are technology incubators? Evidence from Italy

A comparison of US and European university-industry $2002 \quad 14.4$ relations in the life sciences

Internationalization of innovation systems: A survey $2006 \quad 18.4$ of the literature

Inward technology-transfer and competitiveness - the

19959.3 role of national innovation systems

Continental, national and sub-national innovation

200213.1 systems - Complementarity and economic growth

Regional systems of innovation: an evolutionary

$1998 \quad 10.3$ perspective

How to unlock regional economies from path dependency? From learning region to learning cluster

National innovation systems, capabilities and economic development

Firms' knowledge-sharing strategies in the global innovation system: Empirical evidence from the flat panel display industry

'Location versus home country advantages' in R\&D $2002 \quad 10.3$ activities: some further results on multinationals' locational strategies

Technology systems and technology policy in an evolutionary framework

The globalization of technology - a new taxonomy
200515.2 
Table 4 (continued)

\begin{tabular}{|c|c|c|c|c|c|}
\hline $\mathrm{R}$ & $\mathrm{TC}$ & Author & Document title & PY & $\mathrm{C} / \mathrm{Y}$ \\
\hline 22 & 151 & Sharif, N & $\begin{array}{l}\text { Emergence and development of the National } \\
\text { Innovation Systems concept }\end{array}$ & 2006 & 12.6 \\
\hline 23 & 149 & $\begin{array}{l}\text { Schneider, MR; } \\
\text { Schulze-Bentrop, C; } \\
\text { Paunescu, M }\end{array}$ & $\begin{array}{l}\text { Mapping the institutional capital of high-tech firms: A } \\
\text { fuzzy-set analysis of capitalist variety and export } \\
\text { performance }\end{array}$ & 2010 & 18.6 \\
\hline
\end{tabular}

24138 Acs, ZJ; Autio, E; Szerb, L National Systems of Entrepreneurship: Measurement 201434.5 issues and policy implications

25135 Block, $\mathrm{F}$

Swimming against the current: The rise of a hidden $2008 \quad 13.5$ developmental state in the United States

26134 Viotti, EB

National Learning Systems - A new approach on technological change in late industrializing economies and evidences from the cases of Brazil and South Korea

27129 Autio, E; Kenney, M; Mustar, Entrepreneurial innovation: The importance of context 201432.3 P; Siegel, D; Wright, M

28129 Lundvall, BA

Why study national systems and national styles of innovation?

29123 Sternberg, R; Arndt, O

The firm or the region: What determines the

30117 Filippetti, A; Archibugi, D innovation behavior of European firms? Innovation, structure, and demand

$R$ ranking, $T C$ total citations, $P Y$ year of publication, $C / Y$ citations per year

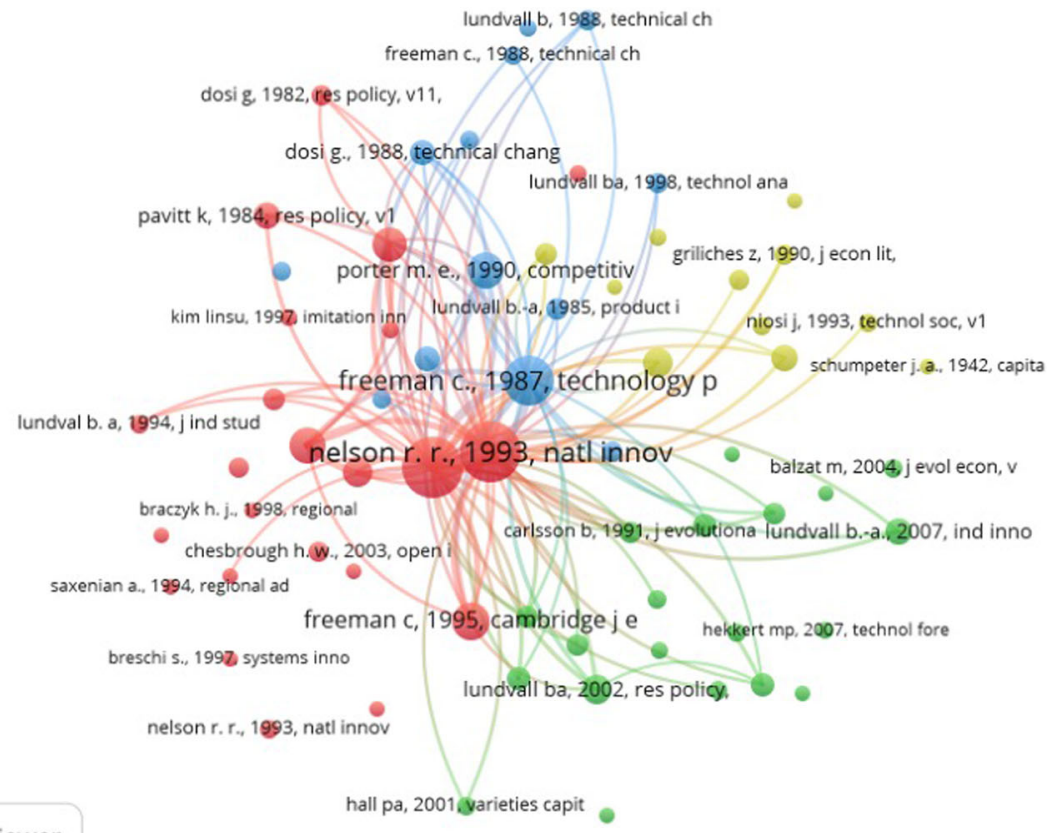

Fig. 4 Co-citation map of references 
Table 5 Descriptive values for co-citation-based clusters with researcher assigned labels

\begin{tabular}{|c|c|c|c|c|c|}
\hline Cluster & $\mathrm{TS}$ & $\mathrm{TC}$ & TLS & Most cited studies & Label \\
\hline 1 (red) & 24 & 1390 & 7475 & $\begin{array}{l}\text { Nelson (1993), Lundvall (1992), } \\
\text { Freeman (1995), Edquist (1997), } \\
\text { Nelson and Winter (1982) }\end{array}$ & $\begin{array}{l}\text { Systemic approach to } \\
\text { innovation }\end{array}$ \\
\hline 2 (blue) & 20 & 665 & 4614 & $\begin{array}{l}\text { Lundvall et al. (2002), Lundvall (2007), } \\
\text { Freeman (2002), Cooke et al. (1997), } \\
\text { Liu and White (2001) }\end{array}$ & $\begin{array}{l}\text { Institutional and } \\
\text { organisational } \\
\text { dimensions }\end{array}$ \\
\hline 3 (green) & 13 & 655 & 3955 & $\begin{array}{l}\text { Freeman (1987), Porter (1990), } \\
\text { Dosi et al. (1988), Lundvall (1985), } \\
\text { OECD (1999) }\end{array}$ & $\begin{array}{l}\text { The economics of } \\
\text { innovation }\end{array}$ \\
\hline 4 (yellow) & 11 & 368 & 2123 & $\begin{array}{l}\text { Etzkowitz and Leydesdorff (2000), } \\
\text { Furman et al. (2002), Patel and } \\
\text { Pavitt (1994), Griliches (1990), } \\
\text { Fagerberg and Srholec (2008) }\end{array}$ & National capabilities \\
\hline
\end{tabular}

TS total studies, TC total citations, TLS total link strength

contemporary overview of NIS research. Figure 5 presents the bibliographic coupling map of these 66 studies and the 100 most representative links. Table 6 groups these results by the VOSviewer clusters.

This analysis reveals seven clusters in the literature. Cluster 6 (in light blue) and Cluster 7 (in orange) were discarded because they comprised only three studies between them. We reviewed the five most cited studies in the other five clusters. We also analysed the rest of the studies in the clusters. We labelled the clusters according to

mowery (2002)

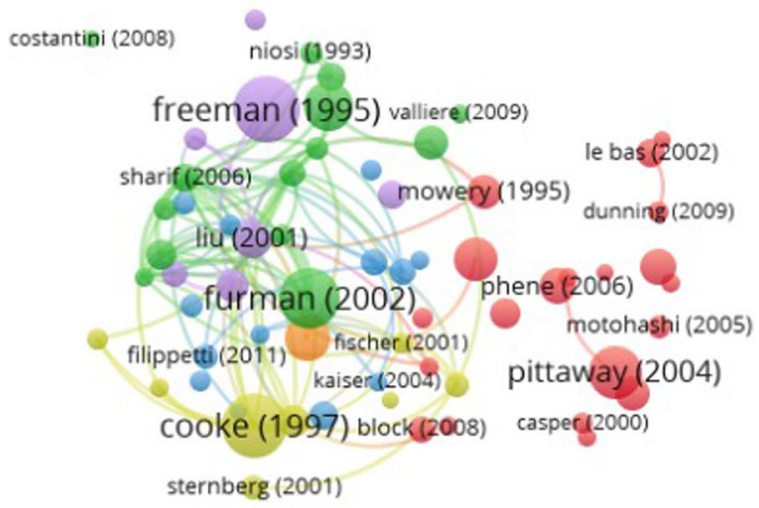

Fig. 5 Bibliographic coupling map of documents 
Table 6 Descriptive values for bibliographic coupling-based clusters with at least five studies with researcher assigned labels

\begin{tabular}{|c|c|c|c|c|c|}
\hline Cluster & TS & $\mathrm{TC}$ & TLS & Most cited studies & Label \\
\hline 1 (red) & 20 & 3101 & 1256 & $\begin{array}{l}\text { Pittaway et al. (2004), Muller } \\
\text { and Zenker (2001), } \\
\text { Phene et al. (2006), } \\
\text { Colombo and Delmastro (2002), } \\
\text { Owen-Smith et al. (2002) }\end{array}$ & $\begin{array}{l}\text { Factors influencing } \\
\text { innovation systems }\end{array}$ \\
\hline 2 (blue) & 14 & 2582 & 2031 & $\begin{array}{l}\text { Furman et al. (2002), } \\
\text { Lundvall et al. (2002), } \\
\text { Carlsson (2006), Fagerberg } \\
\text { and Srholec (2008), } \\
\text { Metcalfe (1995) }\end{array}$ & National capabilities \\
\hline 3 (green) & 13 & 1262 & 1345 & $\begin{array}{l}\text { Schneider et al. (2010), } \\
\text { Acs et al. (2014), } \\
\text { Autio et al. (2014), } \\
\text { Filippetti and } \\
\text { Archibugi (2011), } \\
\text { Martin and Johnston (1999) }\end{array}$ & The dynamics of innovation \\
\hline 4 (yellow) & 9 & 1744 & 1172 & $\begin{array}{l}\text { Cooke et al. (1997), } \\
\text { Cooke et al. (1998), } \\
\text { Faber and Hesen (2004), } \\
\text { Fischer (2001), Gregersen } \\
\text { and Johnson (1997) }\end{array}$ & $\begin{array}{l}\text { Innovation systems under } \\
\text { different transnational, } \\
\text { national and regional } \\
\text { contexts }\end{array}$ \\
\hline 5 (purple) & 7 & 1786 & 818 & $\begin{array}{l}\text { Archibugi and Michie (1995), } \\
\text { Freeman (1995), } \\
\text { Freeman (2002), } \\
\text { Hall et al. (2001), } \\
\text { Liu and White (2001) }\end{array}$ & $\begin{array}{l}\text { Innovation systems under } \\
\text { different transnational, } \\
\text { national and regional } \\
\text { contexts }\end{array}$ \\
\hline
\end{tabular}

TS total studies, TC total citations, TLS total link strength

the main research stream that was common to all of them. The bibliographic coupling analysis gives an up-to-date view of NIS research in terms of four main research streams:

1. Cluster 1: Factors influencing innovation systems, such as networking (Pittaway et al. 2004), business services (Muller and Zenker 2001), technological space and geographical origin (Colombo and Delmastro 2002; Phene et al. 2006) and university-industry relations (Owen-Smith et al. 2002).

2. Cluster 2: National capabilities in terms of technology, patents and R\&D productivity (Metcalfe 1995; Furman et al. 2002), economic growth and development, institutional change and competence building (Lundvall et al. 2002; Fagerberg and Srholec 2008), internationalisation (Carlsson 2006) and other related areas.

3. Cluster 3: The dynamics of innovation, including diffusion and use of technology (Martin and Johnston 1999; Schneider et al. 2010), innovation in times of crisis (Filippetti and Archibugi 2011) and innovations generated by entrepreneurs (Acs et al. 2014; Autio et al. 2014). 
4. Clusters 4 and 5: Innovation systems under different transnational, national and regional contexts.

VOSviewer ranks the clusters based on the number of documents. Cluster 3 has more documents and a greater total link strength than cluster 4 and cluster 5 . However, it has fewer citations. This situation is probably because the five most cited documents in cluster 3 were published recently (all since 2010, except for the study by Martin and Johnston 1999). Therefore, they have had less time to accumulate citations.

\section{Analysis of the Most Common Keywords in NIS Research}

It is also of interest to analyse the most common keywords and their co-occurrence. According to Callon et al. (1983), the analysis of the co-occurrence of keywords can be used to establish the conceptual structure of a research field. Figure 6 presents the map of keyword co-occurrence over the entire period of NIS research (1990-2017) with a threshold of 25 occurrences and the 100 most representative links. The concepts are diverse. Besides, 'NIS', 'innovation' and 'systems', which are a direct result of the search query for this study, 'R\&D', 'technology', 'industry', 'policy', 'science', 'firms', 'knowledge' and 'growth' are the most common keywords in NIS research. The importance of these keywords is consistent with the fact that the innovation systems approach is widespread in knowledge-based economies and learning economies, in both academic and policymaking contexts (Cooke 2001; Lundvall 2016).

To observe how the use of these keywords has evolved, the VOSviewer overlay visualisation and the average publication year variable were used. The colour of the item indicates its average publication year. Table 7 presents these keywords with the number of occurrences and co-occurrences, the average publication year and the
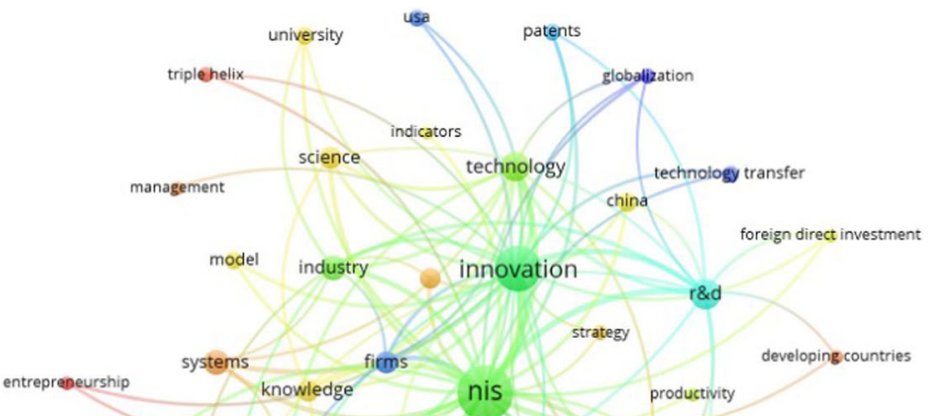

entrepreneurship

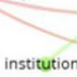

institutions
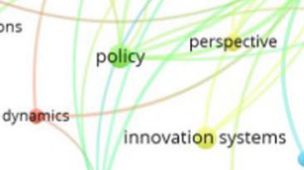

countries

growth

competitiveness

networks

innovation policy

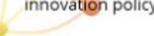

\& vosviewer

ris

Fig. 6 Map of keyword co-occurrence (1990-2017) 
Table 7 Most common keywords

\begin{tabular}{|c|c|c|c|c|c|}
\hline $\mathrm{R}$ & $\mathrm{Kw}$ & $\mathrm{Oc}$ & Co & Avg PY & Cluster \\
\hline 1 & NIS & 373 & 829 & 2010.58 & 3 \\
\hline 2 & Innovation & 253 & 599 & 2010.37 & 2 \\
\hline 3 & $\mathrm{R} \& \mathrm{D}$ & 116 & 380 & 2010.06 & 2 \\
\hline 4 & Technology & 105 & 363 & 2010.74 & 4 \\
\hline 5 & Systems & 80 & 258 & 2011.99 & 1 \\
\hline 6 & Industry & 76 & 277 & 2010.66 & 1 \\
\hline 7 & Policy & 69 & 230 & 2010.68 & 1 \\
\hline 8 & Science & 65 & 219 & 2011.26 & 4 \\
\hline 9 & Firms & 63 & 225 & 2008.70 & 1 \\
\hline 10 & Knowledge & 61 & 241 & 2011.25 & 1 \\
\hline 11 & Growth & 61 & 212 & 2011.97 & 3 \\
\hline 12 & Innovation systems & 60 & 139 & 2010.97 & 1 \\
\hline 13 & Performance & 57 & 183 & 2011.72 & 3 \\
\hline 14 & Networks & 54 & 174 & 2010.28 & 1 \\
\hline 15 & China & 48 & 151 & 2011.08 & 2 \\
\hline 16 & Innovation policy & 48 & 118 & 2012.33 & 5 \\
\hline 17 & University & 45 & 118 & 2011.20 & 4 \\
\hline 18 & Perspective & 42 & 147 & 2011.10 & 1 \\
\hline 19 & Model & 42 & 133 & 2011.10 & 3 \\
\hline 20 & Biotechnology & 36 & 137 & 2009.61 & 1 \\
\hline 21 & Patents & 36 & 127 & 2009.36 & 3 \\
\hline 22 & USA & 35 & 121 & 2008.77 & 4 \\
\hline 23 & Technology transfer & 34 & 91 & 2008.44 & 2 \\
\hline 24 & Economic growth & 33 & 108 & 2011.33 & 5 \\
\hline 25 & Triple Helix & 32 & 99 & 2012.69 & 4 \\
\hline 26 & Dynamics & 31 & 125 & 2012.68 & 1 \\
\hline 27 & Globalisation & 31 & 119 & 2007.90 & 2 \\
\hline 28 & Countries & 31 & 118 & 2012.90 & 3 \\
\hline 29 & Economy & 31 & 94 & 2008.94 & 2 \\
\hline 30 & Institutions & 30 & 110 & 2010.70 & 1 \\
\hline 31 & Strategy & 29 & 106 & 2011.48 & 2 \\
\hline 32 & Competitiveness & 29 & 92 & 2011.10 & 2 \\
\hline 33 & Productivity & 27 & 106 & 2010.89 & 3 \\
\hline 34 & Management & 27 & 89 & 2012.07 & 4 \\
\hline 35 & RIS & 26 & 55 & 2011.23 & 1 \\
\hline 36 & Foreign direct investment & 25 & 89 & 2010.96 & 2 \\
\hline 37 & Indicators & 25 & 89 & 2011.04 & 3 \\
\hline 38 & Entrepreneurship & 25 & 85 & 2013.04 & 1 \\
\hline 39 & Developing countries & 25 & 78 & 2012.28 & 2 \\
\hline
\end{tabular}

$R$ ranking, $K w$ keyword, $O c$ occurrences, $C o$ co-occurrences, $A v g P Y$ average publication year 
VOSviewer cluster sorted by number of occurrences. Interestingly, 'entrepreneurship', 'countries', 'Triple Helix', 'dynamics', 'innovation policy', 'developing countries' and 'management' are the newest keywords (from newest to oldest), with an average publication year of post-2012. The implication is that NIS research increasingly focuses on the relationship between the output of the innovation system and the factors that influence it (Etzkowitz and Leydesdorff 2000; Campbell et al. 2015; Fagerberg 2017) and entrepreneurs as emerging actors who interact with innovation systems (Acs et al. 2014; Autio et al. 2014). This finding corroborates some of the research streams identified in the current overview of the NIS field. The keyword 'developing countries' is linked to the increasing adoption of innovation systems by developing countries. This adoption is reflected by the fact that all the BRICS countries are amongst the biggest producers of NIS research. This keyword also reflects the need to adapt innovation systems to developing countries (Lundvall et al. 2011; Lundvall 2016).

\section{Conclusions}

The aim of this study was to analyse the origins, evolution and prospects of NIS research using bibliometric analysis based on data from the WoS CC database. The analyses included performance analysis and science mapping. The performance analysis used bibliometric indicators such as number of publications, number of citations, h-index and citations per study to evaluate the importance, impact and quality of NIS documents. Science mapping using co-citations, bibliographic coupling and keyword co-occurrence analysis complemented the performance analysis. Bibliometric maps were created using the VOSviewer software. Different units of analysis such as authors, institutions, countries, references, documents and keywords were used.

This study shows that NIS research has grown substantially since 2007. Overall, the UK may be considered the leader in NIS research, with 111 publications and 5007 citations, followed by the USA (120 publications and 3815 citations), and, lagging some distance behind, Germany (54 publications and 1908 citations). Other prominent countries in NIS research are Spain and Italy (with more than 1000 citations each), Denmark (962 citations), the Netherlands (847 citations) and China (844 citations). The BRICS countries minus China (i.e. Brazil, Russia, India and South Africa) are also amongst the countries with the most NIS publications. However, they have poor results in terms of indicators of influence (number of citations, citations per study and h-index).

The analysis of the most common keywords shows that the focus of NIS research has broadened to consider new emerging actors such as entrepreneurs. These actors interact with innovation systems and generate new outputs. The NIS research focus has also grown in scope to address the challenge of adapting the innovation systems approach to developing countries.

The results suggest that developed countries with knowledge-based economies and learning economies focus strongly on NIS research to foster economic growth, competitiveness and diversification. However, developing countries are also increasingly adopting the innovation systems approach.

The co-citation analysis provides a historical view of NIS research. The analysis highlighted four fundamental pillars: (1) the systemic approach to innovation, (2) institutional and organisational dimensions, (3) the economics of innovation and (4) 
national capabilities regarding university-industry-government relations, innovative capacity, patents, R\&D productivity, technological learning, the openness of the economy and other such factors.

The bibliographic coupling analysis provides a current overview of NIS research, revealing four main research streams: (1) factors influencing innovation systems, such as networking, business services, technological space, geographical origin and university-industry relations; (2) national capabilities in terms of technology, patents, R\&D productivity, economic growth and development, institutional change and competence building; (3) the dynamics of innovation, including diffusion and use of technology, innovation in times of crisis or the innovations generated by entrepreneurs; (4) innovation systems under different transnational, national and regional contexts.

Table 8 highlights the changes from the historical view to contemporary NIS research. This table illustrate the direction of current research, where scholars seek ways to contribute to the academic discussion about this topic. Table 8 shows that research has moved towards studies that investigate the factors influencing innovation, national capabilities, the dynamics or output of innovation systems and the development of innovation systems in different transnational, national and regional environments. However, a review of the most cited contributions in these clusters reveals that the boundaries are blurred and that there is a certain degree of overlap between these areas.

The topics addressed by recent studies in each contemporary cluster and the most common keywords with the most recent average year of publication can be used to propose a research agenda for the future development of the NIS literature:

(1) The first item on the agenda is the adaptation of innovation systems to the context of the current global economic crisis and the application of the Quintuple Helix model to cope with this new scenario (Carayannis et al. 2012; Campbell et al. 2015). As previously explained, the concept of the NIS originated during debates on European industrial policy as these developed countries searched to transform their economies into knowledge-based economies. Similarly, the Triple Helix model is based on innovation experience in developed countries. In these countries, relationships between universities (science), industry (business) and government (public administration) have been observed to be paramount for innovation and economic growth in a knowledge-based economy. We are facing a long-term global economic crisis due to the COVID-19 pandemic. This crisis will be aggravated by other global issues such as climate change and the current decline

Table 8 Changes in NIS literature based on the labelled clusters

\begin{tabular}{cll}
\hline No. & Historical view from CoC & Contemporary view from BbC \\
\hline 1 & Systemic approach to innovation & Factors influencing innovation systems \\
2 & Institutional and organisational dimensions & National capabilities \\
3 & The economics of innovation & The dynamics of innovation \\
4 & National capabilities & Innovation systems under different transnational, \\
& & national and regional contexts
\end{tabular}

CoC co-citation, $B b C$ bibliographic coupling 
in the quality of democracy. Innovation systems must adapt to this new scenario in knowledge-based economies. The Quintuple Helix model has massive potential in this new global scenario.

(2) The second item on the agenda is the adaptation of innovation systems to developing countries (Lundvall et al. 2011; Lundvall 2016). Developing countries are increasingly adopting the innovation systems approach as the basis for their innovation policies. Innovation systems must be adapted to the idiosyncrasies of each developing country.

(3) The third item on the agenda is the fit of entrepreneurship and entrepreneurial innovations in NIS research (Acs et al. 2014; Autio et al. 2014). Entrepreneurship fits into NIS research in specific ways, as explained by Acs et al. (2014, p. 476):

National Systems of Entrepreneurship are fundamentally resource allocation systems that are driven by individual-level opportunity pursuit, through the creation of new ventures, with this activity and its outcomes regulated by country-specific institutional characteristics. In contrast with the institutional emphasis of the National Systems of Innovation frameworks, where institutions engender and regulate action, National Systems of Entrepreneurship are driven by individuals, with institutions regulating who acts and the outcomes of individual action. (Acs et al. 2014, p. 476)

Finally, the possible limitations of this study should be noted. First, NIS research documents that are not indexed in the WoS CC were not included in the analysis. Notable documents that were missing from the analysis include the pioneering books by Lundvall, Nelson and Freeman. However, this study partially overcame this limitation by using science mapping. This technique lent robustness to the results because the cited references were not required to be indexed in the WoS CC to be included in the analysis. Another limitation is that the complete counting system of the WoS CC means that documents attributed to multiple authors or affiliations tend to have a higher weighting in the analysis than papers with a single author because one unit is assigned to each researcher, regardless of the number of authors. Despite these limitations, this study nonetheless successfully identifies key results regarding the future evolution and prospects of NIS research.

\section{References}

Acs, Z. J., Autio, E., \& Szerb, L. (2014). National systems of entrepreneurship: measurement issues and policy implications. Research Policy, 43(3), 476-494. https://doi.org/10.1016/j.respol.2013.08.016.

Archibugi, D., \& Michie, J. (1995). The globalisation of technology: a new taxonomy. Cambridge Journal of Economics, 19(1), 121-140. https://doi.org/10.1093/oxfordjournals.cje.a035299.

Autio, E., Kenney, M., Mustar, P., Siegel, D., \& Wright, M. (2014). Entrepreneurial innovation: the importance of context. Research Policy, 43(7), 1097-1108. https://doi.org/10.1016/j.respol.2014.01.015.

Bergek, A., Jacobsson, S., Carlsson, B., Lindmark, S., \& Rickne, A. (2008). Analyzing the functional dynamics of technological innovation systems: a scheme of analysis. Research Policy, 37(3), 407-429. https://doi.org/10.1016/j.respol.2007.12.003.

Borras, S., \& Edquist, C. (2013). The choice of innovation policy instruments. Technological Forecasting and Social Change, 80(8), 1513-1522. https://doi.org/10.1016/j.techfore.2013.03.002. 
Callon, M., Courtial, J. P., Turner, W. A., \& Bauin, S. (1983). From translations to problematic networks: an introduction to co-word analysis. Social Science Information, 22(2), 191-235. https://doi.org/10.1177/ 053901883022002003.

Campbell, D. F. J., Carayannis, E. G., \& Rehman, S. S. (2015). Quadruple helix structures of quality of democracy in innovation systems: the USA, OECD countries, and EU member countries in global comparison. Journal of the Knowledge Economy, 6, 467-493. https://doi.org/10.1007/s13132-0150246-7.

Carayannis, E. G., Barth, T. D., \& Campbell, D. F. J. (2012). The quintuple helix innovation model: global warming as a challenge and driver for innovation. Journal of Innovation and Entrepreneurship, 1, 1-12. https://doi.org/10.1186/2192-5372-1-2.

Carlsson, B. (2006). Internationalization of innovation systems: a survey of the literature. Research Policy, 35(1), 56-67. https://doi.org/10.1016/j.respol.2005.08.003.

Chiang, J. T. (1990). Management of national technology programs in a newly industrialized country Taiwan. Technovation, 10(8), 531-554. https://doi.org/10.1016/0166-4972(90)90049-P.

Cobo, M. J., López-Herrera, A. G., Herrera-Viedma, E., \& Herrera, F. (2011). Science mapping software tools: review, analysis, and cooperative study among tools. Journal of the American Society for Information Science and Technology, 62(7), 1382-1402. https://doi.org/10.1002/asi.21525.

Colombo, M. G., \& Delmastro, M. (2002). How effective are technology incubators?: evidence from Italy. Research Policy, 31(7), 1103-1122. https://doi.org/10.1016/S0048-7333(01)00178-0.

Cooke, P. (2001). Regional innovation systems, clusters, and the knowledge economy. Industrial and Corporate Change, 10(4), 945-974. https://doi.org/10.1093/icc/10.4.945.

Cooke, P., Uranga, M. G., \& Etxebarria, G. (1997). Regional innovation systems: institutional and organisational dimensions. Research Policy, 26(4-5), 475-491. https://doi.org/10.1016/S0048-7333(97) 00025-5.

Cooke, P., Uranga, M. G., \& Etxebarria, G. (1998). Regional systems of innovation: an evolutionary perspective. Environment and Planning A, 30, 1563-1584. https://doi.org/10.1068/a301563.

Dosi, G., Freeman, C., Nelson, R., Silverberg, G., \& Soete, L. (Eds.). (1988). Technical change and economic theory. London: Pinter.

Edquist, C. (Ed.). (1997). Systems of innovation: technologies, institutions and organizations. London: Frances Pinter.

Edquist, C. (2004). Systems of innovation: perspectives and challenges. In J. Fagerberg, D. Mowery, \& R. Nelson (Eds.), Oxford handbook of innovation (pp. 181-208). Oxford: Oxford University Press.

Egghe, L. (2006). Theory and practice of the g-index. Scientometrics, 69(1), 131-152. https://doi.org/10.1007/ s11192-006-0144-7.

Etzkowitz, H., \& Leydesdorff, L. (2000). The dynamics of innovation: from National Systems and "Mode 2" to a Triple Helix of university-industry-government relations. Research Policy, 29, 109-123. https://doi. org/10.1016/S0048-7333(99)00055-4.

European Commission. (2014). The European Union explained: Research and innovation (Vol. 2014). Luxembourg: Publications Office of the European Union. https://doi.org/10.2775/74012.

Faber, J., \& Hesen, A. B. (2004). Innovation capabilities of European nations: cross-national analyses of patents and sales of product. Research Policy, 33(2), 193-207. https://doi.org/10.1016/S0048-7333(03) 00122-7.

Fagerberg, J. (2017). Innovation policy: rationales, lessons and challenges. Journal of Economic Surveys, 31(2), 497-512. https://doi.org/10.1111/joes.12164.

Fagerberg, J., \& Srholec, M. (2008). National innovation systems, capabilities and economic development. Research Policy, 37(9), 1417-1435. https://doi.org/10.1016/j.respol.2008.06.003.

Filippetti, A., \& Archibugi, D. (2011). Innovation in times of crisis: National Systems of Innovation, structure, and demand. Research Policy, 40(2), 179-192. https://doi.org/10.1016/j.respol.2010.09.001.

Fischer, M. (2001). Innovation, knowledge creation and systems of innovation. The Annals of Regional Science, 35, 199-216. https://doi.org/10.1007/s001680000034.

Flanagan, K., Uyarra, E., \& Laranja, M. (2011). Reconceptualising the 'policymix' for innovation. Research Policy, 40(5), 702-713. https://doi.org/10.1016/j.respol.2011.02.005.

Freeman, C. (1987). Technology policy and economic performance: lessons from Japan. Pinter Publishers.

Freeman, C. (1995). The National System of Innovation in historical perspective. Cambridge Journal of Economics, 19, 5-24. https://doi.org/10.1093/oxfordjournals.cje.a035309.

Freeman, C. (2002). Continental, national and sub-national innovation systems - complementarity and economic growth. Research Policy, 31(2), 191-211. https://doi.org/10.1016/S0048-7333(01)00136-6.

Furman, J. L., Porter, M. E., \& Stern, S. (2002). The determinants of national innovative capacity. Research Policy, 31(6), 899-933. https://doi.org/10.1016/S0048-7333(01)00152-4. 
Garfield, E. (2001). From bibliographic coupling to co-citation analysis via algorithmic historio-bibliography: a citationist's tribute to Belver C. Griffith. Philadelphia: Drexel University.

Glänzel, W., \& Czerwon, H. J. (1996). A new methodological approach to bibliographic coupling and its application to the national, regional and institutional level. Scientometrics, 37, 195-221. https://doi.org/ 10.1007/BF02093621.

Gregersen, B., \& Johnson, B. (1997). Learning economics, innovation systems and European integration. Regional Studies, 31(5), 479-490. https://doi.org/10.1080/00343409750132270.

Griliches, Z. (1990). Patent statistics as economic indicators: a survey. Journal of Economic Literature, 28(4), 1661-1707 https://www.jstor.org/stable/2727442.

Hall, A., Bockett, G., Taylor, S., Sivamohan, M. V. K., \& Clark, N. (2001). Why research partnerships really matter: innovation theory, institutional arrangements and implications for developing new technology for the poor. World Development, 29(5), 783-797. https://doi.org/10.1016/S0305-750X(01)00004-3.

Hirsch, J. E. (2005). An index to quantify an individual's scientific research output. Proceedings of the National Academy of Sciences of the United States of America, 102, 16569-16572. https://doi.org/10. 1073/pnas.0507655102.

Jarvening, B. (2007). Bibliographic coupling and its application to research-front and other core documents. Journal of Informetrics, 1(4), 287-307. https://doi.org/10.1016/j.joi.2007.07.004.

Kessler, M. M. (1963). Bibliographic coupling between scientific papers. American Documentation, 14, 10 25. https://doi.org/10.1002/asi.5090140103.

List, F. (1841). The national system of political economy. English Edition (1904). London, Longman.

Liu, X., \& White, S. (2001). Comparing innovation systems: a framework and application to China's transitional context. Research Policy, 30(7), 1091-1114. https://doi.org/10.1016/S0048-7333(00)001323.

López-Rubio, P., Roig-Tierno, N., \& Mas-Verdú, F. (2018). Technology transfer: a comparison between Web of Science Core Collection and Scopus. Information and Innovations, 13(2), 53-69. https://doi.org/10. 31432/1994-2443-2018-13-2-53-69.

López-Rubio, P., Roig-Tierno, N., \& Mas-Tur, A. (2020). Regional innovation system research trends: toward knowledge management and entrepreneurial ecosystems. International Journal of Quality Innovation, 6(1), 1-16. https://doi.org/10.1186/s40887-020-00038-x.

Lundvall, B. A. (1985). Product innovation and user-producer interaction. Available at: https://www. researchgate.net/publication/251542478_Product_Innovation_and_User-Producer_Interaction.

Lundvall, B. A. (1992). National systems of innovation: towards a theory of innovation and interactive learning. London: Pinter.

Lundvall, B. A. (2007). National Innovation Systems - analytical concept and development tool. Industry \& Innovation, 14, 95-119. https://doi.org/10.1080/13662710601130863.

Lundvall, B. A. (2016). The learning economy and the economics of hope. NY: Anthem Press ISBN: 9781783085965.

Lundvall, B. A., Johnson, B., Andersen, E. S., \& Dalum, B. (2002). National systems of production, innovation and competence-building. Research Policy, 31(2), 213-231. https://doi.org/10.1016/S00487333(01)00137-8.

Lundvall, B. A., Joseph, K. J., Chaminade, C., \& Vang, J. (2011). Handbook of innovation systems and developing countries. Building Domestic Capabilities in a Global Setting. In B. A. Lundvall, K. J. Joseph, C. Chaminade, \& J. Vang (Eds.), ISBN: 9781847206091.

Martin, B. (1996). The use of multiple indicators in the assessment of basic research. Scientometrics, 36(3), 343-362. https://doi.org/10.1007/BF02129599.

Martin, C. R., \& Johnston, R. (1999). Technology foresight for wiring up the National Innovation System: experiences in Britain, Australia, and New Zealand. Technological Forecasting and Social Change, 60(1), 37-54. https://doi.org/10.1016/S0040-1625(98)00022-5.

McKelvey, M. (1991). How do National Systems of Innovation differ?: a critical analysis of Porter, Freeman, Lundvall and Nelson. In G. M. Hodgson \& E. Screpanti (Eds.), Rethinking economics. Markets, technology and economics evolution (pp. 117-137). Aldershot: Elgar, ISBN 1852784164.

Metcalfe, J. S. (1995). Technology systems and technology policy in an evolutionary framework. Cambridge Journal of Economics, 19(1), 25-46. https://doi.org/10.1093/oxfordjournals.cje.a035307.

Mowery, D. C. (1992). The U.S. National Innovation System: origins and prospects for change. Research Policy, 2l(2), 125-144. https://doi.org/10.1016/0048-7333(92)90037-5.

Muller, E., \& Zenker, A. (2001). Business services as actors of knowledge transformation: the role of KIBS in regional and national innovation systems. Research Policy, 30(9), 1501-1516. https://doi.org/10.1016/ S0048-7333(01)00164-0. 
Nelson, R. R. (1993). National Innovation Systems. A comparative analysis. Edited by Richard R. Nelson. ISBN: 9780195076172.

Nelson, R., \& Winter, S. (1982). An evolutionary theory of economic change. Cambridge: Bellknap.

OECD. (1996). The knowledge-based economy. Paris: OECD Publishing.

OECD. (1999). Managing National Innovation Systems. Paris: OECD Publishing.

OECD. (2011). Regions and innovation policy. OECD Reviews of Regional Innovation. Paris: OECD Publishing.

OECD. (2015). The innovation imperative: contributing to productivity, growth and well-being. Paris: OECD Publishing. https://doi.org/10.1787/9789264239814-en.

Owen-Smith, J., Riccaboni, M., Pammolli, F., \& Powell, W. W. (2002). A comparison of U.S. and European university-industry relation in the life sciences. Management Science, 48(1), 1-34. https://doi.org/10. 1287/mnsc.48.1.24.14275.

Patel, P., \& Pavitt, K. (1994). National innovation systems: why they are important, and how they might be measured and compared. Economics of Innovation and New Technology, 3(1), 77-95. https://doi.org/10. 1080/10438599400000004.

Phene, A., Fladmoe-Lindquist, K., \& Marsh, L. (2006). Breakthrough innovations in the U.S. biotechnology industry: the effects of technological space and geographic origin. Strategic Management Journal, 27(4), 369-388. https://doi.org/10.1002/smj.522.

Pittaway, L., Robertson, M., Munir, K., \& Neely, A. (2004). Networking and innovation: a systematic review of the evidence. International Journal of Management Reviews, 5/6(3\&4), 137-168. https://doi.org/10. 1111/j.1460-8545.2004.00101.x.

Porter, M. (1990). The competitive advantages of nations. The Free Press Edition.

Schneider, M. R., Schulze-Bentrop, C., \& Paunescu, M. (2010). Mapping the institutional capital of high-tech firms: a fuzzy-set analysis of capitalist variety and export performance. Journal of International Business Studies, 41, 246-266. https://doi.org/10.1057/jibs.2009.36.

Small, H. (1973). Co-citation in the scientific literature: a new measure of relationship between two documents. Journal of the American Society for Information Science, 24, 265-269.

Small, H. (1999). Visualizing science by citation mapping. Journal of the American Society for Information Science, 50(9), 799-813. https://doi.org/10.1002/(SICI)1097-4571(1999)50:9<799::AID-ASI9>3.0.CO; $2-\mathrm{G}$.

Suominen, A., Seppänen, M., \& Dedehayir, O. (2019). A bibliometric review on innovation systems and ecosystems: a research agenda. European Journal of Innovation Management, 22(2), 335-360. https:// doi.org/10.1108/EJIM-12-2017-0188.

Van Eck, N. J., \& Waltman, L. (2010). Software survey: Vosviewer, a computer program for bibliometric mapping. Scientometrics, 84(2), 523-538. https://doi.org/10.1007/s11192-009-0146-3.

Vertova, G. (2014). The state and national systems of innovation: a sympathetic critique. The Levy Institute Working Paper Collection. Working Paper No. 823.

White, H. D., \& Griffith, B. C. (1981). Author co-citation: a literature measure of intellectual structure. Journal of the American Society for Information Science, 21, 163-172. https://doi.org/10.1002/asi. 4630320302.

Youtie, J., Kay, L., \& Melkers, J. (2013). Bibliographic coupling and network analysis to assess knowledge coalescence in a research center environment. Research Evaluation, 22(3), 145-156. https://doi.org/10. 1093/reseval/rvt002.

Publisher's Note Springer Nature remains neutral with regard to jurisdictional claims in published maps and institutional affiliations.

\section{Affiliations}

\section{Pedro López-Rubio $^{1}$ • Norat Roig-Tierno ${ }^{2} \cdot$ Francisco Mas-Verdú $^{1}$}

1 Departamento de Economía y Ciencias Sociales, Universitat Politècnica de València (UPV), Camino de Vera, s/n, Valencia, Spain

2 ESIC Business \& Marketing School, Av. de Blasco Ibáñez, 55, Valencia, Spain 